\title{
SYMPOSIUM ON CRITICAL PERSPECTIVES ON HUMAN SHIELDS
}

\section{HUMAN SHIELDS/HUMAN CROSSHAIRS: COLONIAL LEGACIES AND CONTEMPORARY WARS}

\author{
Vasuki Nesiab*
}

The nomenclature of human shields did not exist in $19^{\text {th }}$ century colonialism, but one can find its proxies in the debates regarding the principles of distinction and proportionality when defining legitimate targets. Its specters appeared in the discussions weighing human life and moderating warfare, revealing how the imperatives of colonial conquest inflected "humanitarian reason" and its epistemic and political investments. ${ }^{1}$ The colonized territory rendered all civilians as potential human shields merely by existing there. The colonizer/colonized distinction trumped the civilian/combatant distinction and exposed the radical instability of the principles defining the notion of human shields; the colonizer seldom thought he had reached the threshold of disproportionality in violence against the colonized. Instead, the "civilizing mission" rendered the colonized body perennially vulnerable.

This essay interrogates how this relationship between human shields and collateral damage is articulated; how human shields, a term defined by the civilian/combatant distinction, becomes intertwined with its opposite, the notion that the treatment of civilians as combatants - thus indistinction-is inevitable. It accordingly suggests that today, the language of "humanity" and "counterterrorism" converge in the discourse of "human shields" to facilitate a parallel dynamic in countries facing the brunt of contemporary "great power" militarization; residents in countries such as Afghanistan, Yemen, and Syria are rendered perennially vulnerable when framed as victims of belligerent forces deploying "human shields." By situating human shields in the colonial genealogy of the combatant/civilian distinction (and its undoing), I argue that while the language of human shields is advanced in the name of protecting civilians, often, it is also doing the opposite; namely, it is translating contemporary iterations of colonized or precarious bodies into "legitimate" targets.

\section{The Backstory to Human Shields}

In a much-celebrated episode in the canonical history of humanitarianism, the first Nobel peace laureate, Henry Dunant, passed the battleground of Solferino when on a business trip in 1859. Distraught at the plight of the injured and the dead in this war between France and Austria, Dunant advocated for the notion of a "humanitarian" war, and legal and institutional avenues implementing that vision. ${ }^{2}$ Dunant's reflections and the activism of leading citizens in Geneva led to the founding of the Red Cross in 1863, and a Convention on the Laws of War. ${ }^{3}$ The

* My thanks to Ioannis (Yannis) Kalpouzos for pointing me to the Algerian Office's White Paper on the Application of the Geneva Conventions of 1949 to the French-Algerian Conflict.

${ }^{1}$ Didier Fassin, Humanitarian Reason: A Moral History of the Present (2012).

${ }^{2}$ Henry Dunant, A Memory of Solferino (1939).

${ }^{3}$ Convention for the Amelioration of the Condition of the Wounded in Armies in the Field, August 22, 1864.

\footnotetext{
The American Society of International Law and Vasuki Nesiah (C) 2017. This is an Open Access article, distributed under the terms of the Creative Commons Attribution licence (http://creativecommons.org/licenses/by/4.0/), which permits unrestricted re-use, distribution, and reproduction in any medium, provided the original work is properly cited.
} 
principles of distinction and proportionality underlying the law related to human shields and other elements of the new humanitarian framework were a central anchor of these initiatives.

The back-story to Dunant is less well-known but equally illuminating. Dunant encountered the battlegrounds of Solferino because he was on a business trip from Switzerland to solicit Napoleon III's patronage for his investments in Algeria. Dunant started travelling to Algeria in the 1850s after the French had begun a colonial war of conquest. Dunant was involved in a series of business ventures in the French colonies, including with Compagnie genevoise des Colonies de Sétif (The Geneva Company of Colonies of Setif), and had travelled to Algeria several times. Amongst other duties, Dunant was entrusted with securing a land grant in Algeria, and facilitating European settlers access to local resources. He is described as an "enthusiastic colonizer" motivated by the extraction of profits as well as the "civilizing mission of Christians" in a Moslem country. This civilizational prism profited colonial commercial interests but it also framed how Dunant experienced the war in Solferino as a tragedy for all parties, and the war to colonize Algeria as good fortune for all concerned.

The French invasion of Algeria took place in 1830; the war to establish administrative control took another forty plus years. Ben Kiernan describes this process of military and political consolidation as a genocide that extended from 1830 to 1875 and killed almost one million Algerians. ${ }^{5}$ Were they combatants? Civilians? Human Shields? What do these terms mean in a war of colonization? In 1843, a French officer, Lieutenant-Colonel de Montagnac, described the strategy and philosophy of the military operation in Algeria thus:

All populations who do not accept our conditions must be despoiled. Everything must be seized, devastated, without age or sex distinction: grass must not grow any more where the French army has set foot. Who wants the end, wants the means, whatever may say our philanthropists. I personally warn all good soldiers whom I have the honor to lead that if they happen to bring me a living Arab, they will receive a beating with the flat of the saber ... . This is how, my dear friend, we must make war against Arabs: kill all men over the age of fifteen, take all their women and children, load them onto naval vessels, send them to the Marquesas Islands or elsewhere. In one word, annihilate all who will not crawl beneath our feet like dogs. ${ }^{6}$

Indigenous populations that opposed the military invasion could be exterminated indiscriminately, as an indistinct block. These were the ethical coordinates of the battlefield within which Dunant sought profits unclouded by concerns regarding the barbarity of war that so motivated his response to Solferino. Algeria was a business opportunity and a call to Christianization; Solferino was a human tragedy calling for compassion and dignity.

The intertwined histories of the birth of modern humanitarian law in European theaters such as Solferino and colonial theaters such as Algeria are central to the genealogy of "human shields." Dunant's divergent investments, ethical and commercial, in Solferino and Algeria, were typical of the $19^{\text {th }}$ century humanitarians. International Committee of the Red Cross (ICRC) co-founder, Gustave Moynier, was, for instance, an enthusiastic supporter of King Leopold in the Congo and Honorary Consul General of the Congo Free State in Switzerland. ${ }^{7}$ ICRC headquarters and the Congo consulate even shared premises. ${ }^{8}$ In fact, that shared office symbolizes how expressions of concern for the value of life contributed to legitimizing a space of permissible harm in the colonies.

\footnotetext{
${ }^{4}$ Odette Goinard, Henry Dunant, MemioreafriqueduNord.

${ }^{5}$ Ben Kiernan, Blood and Soil: A World History of Genocide and Extermination from Sparta to Darfur (2007).

${ }^{6}$ De Montagnac, Lettres D'un Soldat (1885); Laura Rahme, Montagnac - A man of contradictions?, Teranga (Feb. 1, 2011).

7 Thomas Cottier et al., Gustave Moynier, in The Anthology of Swiss Legal Culture (Thomas Cottier et al. eds., 2015).

8 See Daniel Palmieri, An institution standing the test of time?, 95 ICRC Rev. 1, n.57 (2013).
} 
The ICRC was a European organization, invested in Europe's presentation of its role in the world in civilizational terms, and the notion that "mercy and compassion were uniquely Christian values." "The colonialist ethos shaped the ICRC well into the $20^{\text {th }}$ Century. The ICRC's initial ambivalence about condemning the 1935 Italian invasion of Ethiopia (using mustard gas and aerial bombardment in civilian areas) was indicative of the organization's conception of colonization as a welcome Europeanization of a lesser civilization. ${ }^{10}$ The discourse of "humanitarian ethics" and "civilization" converged to produce a uniquely European approach to the laws of war and humanitarian principles that was contrasted with a colonial "other." Within this logic, the legitimacy of wars fought to colonize Algeria or the Congo by any means necessary, and the concomitant suspension of humanitarian principles, was determined by the colonizer/colonized distinction not the civilian/combatant distinction.

The colonial antecedents illuminate how the background assumptions of humanitarian protection can refuse space for legitimate resistance. Within the moral arithmetic of colonization, the test for proportionality and distinction calculates who qualifies as a legitimate target. For instance, in de Montagnac's calculation ("All populations who do not accept our conditions must be despoiled") to resist colonization is to become a killable "voluntary human shield." Today too a moral arithmetic aligned with dominant military forces determines which bodies are valued, and which ones have forfeited rights to protection by humanitarian laws, policies, and institutions. ${ }^{11}$ Thus, from Rachel Corrie in Palestine ${ }^{12}$ to the White Helmets in Syria, ${ }^{13}$ even nonviolent and nonpartisan resistance of third parties is assessed in terms of military benefit or loss to the dominant military power. When the United States says that antiwar activists in Iraq will be treated as servicing the opponent, of having "crossed the line between combatant and noncombatant," it is saying that peace activists do not have legitimacy to "shield" because their resistance is too costly for the U.S. military. ${ }^{14}$

In some colonial contexts, as the colonizer/colonized distinction overdetermined the civilian/combatant distinction, even the category of "civilian" becomes a sign of categorical confusion. ${ }^{15}$ If the notion of a colonial civilian was an inconceivable oxymoron, colonized bodies could not be shields that weighted humanitarian considerations in arresting attack; colonized bodies were, by definition, indistinctively dispensable. From Algeria to the Congo, violence against the colonized was often indiscriminate and genocidal.

With parallels to the space for the civilizing mission, today the space for collateral damage is shaped by the hierarchies and inequalities of global civil society, including those anchored in political-economy, nationality, race, and religion. These parallels illuminate the domain of indiscriminate violence and constitute the backdrop against which the "civilian" gets defined and protected. Clarified by juxtaposition with the privileged civilian subject, the background domain gets emptied of civilians in law, even if not in fact. Thus, in the art of the humanitarian framework, the background domain becomes a negative space representing what humanitarian law renders precarious. Yesterday, these spaces were inhabited by the colonized; today, they are inhabited by figures constituting the international law inventory of collateral damage, like the human shield.

\footnotetext{
${ }^{9}$ Michelle Barnett, Empire of Humanity: A History of Humanitarianism 81 (2011).

${ }^{10} \mathrm{Id}$. at 92 .

11 The voluntary and involuntary human shielding distinction, definitions of resistance, are profoundly troubled when people are rendered vulnerable because they don't act on an order to leave, because they protect their homes or use their own hospitals.

${ }^{12}$ Rory McCarthy, Rachel Corrie's family bring civil suit over human shield's death in Gaza, TheGuardian (Feb. 23, 2010).

${ }^{13}$ WhiteHelmets.

${ }^{14}$ U.S. Gen. Tommy Franks is quoted in 'Human Shields' May Be Considered Combatants, L.A. Times (Feb. 27, 2003).

${ }^{15}$ Neve Gordon and Nicola Perugini argue that there is no such thing as a civilian in a colonized space; see NEvE GORDON \& NicOLA Perugini, The Human Right to Dominate (2016).
} 


\section{The Wars of Liberation: Situating Human Shields in the Crimes of the Colonists}

The 1949 Geneva Conventions pulled "human shields" into its black letter corpus through Article 28 of the Fourth Geneva conventions: "The presence of a protected person may not be used to render certain points or areas immune from military operations." 16 Five years later, November 1, 1954, the National Liberation Front (FLN) launched major demonstrations and attacks and launched a new phase in the Algerian war of independence. With the French framing this war as a domestic policing problem, the applicability of the Geneva Conventions itself became a terrain of battle. From forfeiting protections reserved for civilians because the colonized are excluded by civilizational difference we move to forfeiting protections reserved for civilians because the colonized are included in the ranks of citizenship — and thus of civilianhood. This is inclusion within the nation but exclusion from protection — what Kojo Koram has referred to in another context as "inclusive exclusion," namely inclusion within the order but with an exclusionary logic. ${ }^{17}$

In 1960, the Algerian Provisional Government submitted a white paper on the applicability of the Geneva Conventions to the Algerian liberation war. ${ }^{18}$ The Provisional Government committed to ratifying the Geneva Conventions. Mohamed Bedjaoui, legal advisor to the FLN and the Provisional Government, recognized that efforts to frame the struggle in citizenship versus public international law terms made all the difference in determining which "crimes" were foregrounded-the violations of domestic criminal law or the "crimes of colonists." 19 The former would give France an alibi "amid the bloodstained horrors of an unforgivable war under shelter of plea that the laws of humanitarian conventions do not apply." ${ }^{20}$ If, in the war of colonization, the Algerian body become a legitimate military target by defining war as a civilizing mission, in the war of decolonization, the Algerian body becomes a legitimate military target by defining war as a law and order project.

It is significant that in the wars of decolonization, it was liberation groups such as the FLN and the African National Congress that advocated for the widest reach of IHL. Algerian bodies in the line of fire were not obstructing police action against criminals, but instead were victims of the "crimes of colonists" - victims of "the organized use of torture, summary executions, the practice of genocide," and more. ${ }^{21}$ The white paper argued that the French use of indiscriminate and disproportionate violence to suppress the liberation struggle were violations of international law. Bedjoui noted that calling the war of liberation a matter of domestic criminality enables war crimes. The struggle over naming crimes is a struggle to frame the war of liberation not as criminal action but as ethical violence against the prior crime of colonization—a just war.

\section{Humanity and Necessity in the Balance}

The dynamics that attended law and war in the context of decolonization is instructive for understanding the work of "human shield" discourse today. In a recent commentary on "human shields" and the legal status of attacks on hospitals, Kevin Jon Heller argues for "an appropriate balance between humanity and necessity" in

${ }^{16}$ Geneva Convention, Relative to the Protection of Civilian persons in Time of War, Aug. 12, 1949, 75 UNTS 287.

17 The Colonial Encounter and The Construction of a Sacrificial International, Presentation at Tricontinental Conference, Portugal, Sept. 2016.

18 Algerian Office, White Paper on the Application of the Geneva Conventions of 1949 to the French-Algerian Conflict (1960).

19 Mohammed Bedjaoui, Law and the Algerian Revolution (1961).

${ }^{20}$ Bedjoui quoted in Amanda Alexander, International Humanitarian Law, Postcolonialism and the 1977 Geneva Protocol I, 17 MeLbourne J. INT'L L. 15, 26 (2016)

${ }^{21}$ Id. at 29. 
criticizing those who want to ban all attacks on hospitals. ${ }^{22}$ Heller maintains that a ban on bombing hospitals used as shields would be unreasonable. The most significant and telling word in his description of those conditions is the word "balance" because it renders the invocation of humanity as internal to the logic of targeting a hospital that served as a shield for militants. The determination of what should or should not be considered a war crime integrates humanity and necessity; it reconciles questions of moral rationale with military calculations of costs and benefits. From bombs dropped on "hospital shields" to drones killing wedding parties, this accommodation of collateral damage into strategic imperatives is part of the grammar informing the human shields discussion today.

Someone, somewhere assumes the authority to balance humanity and necessity and to decide that it was necessary to bomb hospitals or launch killer drones in Pakistan and Somalia while killing so-called human shields. The moral rationale informing these kinds of military calculations ends up distributing costs amongst different humans. Some humans are systemic beneficiaries of the balancing calculations, that give weight to the "necessity" side of the scale, while other humans are rendered dispensable by this type of accounting. Thus, the term balance also presupposes an imbalance or asymmetry between those who have the power to decide how humanity and necessity get integrated, and those who end up bearing the price of these decisions. For the notion of humanity to mediate the prohibition of using human shields in ways that enable the military machine to move forward, requires a splitting of the "human" along the lines that it was split during colonialisms of old, a constitutive asymmetry internal to the notion of humanity and its putative universality.

Echoing how the civilizing mission functioned in the moral arithmetic of colonialism, today, the stakes of war are described using the register of humanity. Mosul, Aleppo, Gaza, Kandahar land on our headlines as places with stakes not only for the humans living in those territories but for all humanity. How then do we calculate the balance? How do we balance the costs to all humanity and the costs to civilians living in those territories? The invocation of "humanity" already tips the scales, and overdetermines the results of that calculation. Residents living in those areas are potentially human shields merely by existing in those territories. Increasingly, war is brought to civilian zones and civilians who do not leave are seen as voluntary human shields-legitimate collateral damage whose legal rights are in abeyance.

A sign of the significance of human shields for humanity, in October 2016, none other than the UN High Commissioner for Human Rights declared that ISIL relocated Iraqis from neighboring regions into Mosul "to use the presence of civilians to render certain points, areas or military forces immune from military operations, effectively using tens of thousands of women, men and children as human shields." 23 In turn, the U.S. military declared that "The party that employs human shields in an attempt to shield military objectives from attack assumes responsibility for their injury, provided that the attacker takes feasible precautions in conducting its attack." Taken together, both these statements, contribute to the moral, military, and legal arithmetic that will shape how humanity and necessity are balanced in determining the fate of the residents of Mosul going forward.

Reports that thousands of civilians have been transformed into human shields in Mosul maps Mosul as a context where every civilian is potential collateral damage. As outrage expressing intolerance for the deployment of human shields heightens, tolerance for collateral damage also heightens. Advance mapping of human shields prepares us for the sacrifice of humans for the protection of humans - in particular, the sacrifice of some humans for the protection of other humans, for "humanity."

The logic of "humanity" operates in an age where the threat is described as ubiquitous, the enemy infinite and the war as perpetual. The battlefield is not the five-square-mile territory of Solferino but potentially infinite with "no areas immune from military operations." The formulation employed in Article 28 of the Fourth Geneva

22 Kevin Jon Heller, Don't Blame IHL for Attacks on "Hospital Shields", OpINioJuris (Oct. 21, 2016, 4:16 AM).

${ }^{23}$ Battle for Mosul: ISIS forces thousands of civilians from their homes and executes hundreds, UN OFFICE OF THE HigH COMMISSIONER FOR HuMAN Rights (Oct. 28, 2016). 
Convention suggests that there is no area that is not already militarized. The problem of human shields is the removing of an area from an infinite battlefield. The war crimes armature coiling around the category of human shields is triggered by the war crime of bringing civilians into a war zone and transforming clean military targets into potential war crimes themselves. In an infinite war zone, there is no space then for protected civilians. The legal definition of human shields and civilian targets (be it in establishing parameters for the protection of civilians or in delineating the parameters of permissible "collateral damage") and the argument about whether the story of a particular episode is written as one or the other war crime, ensures that the law of war is itself weaponized. It is weaponized by those who use civilians as human shields, as well as by those who invoke the defense that the military target necessary and occupied not by "civilians" but by "human shields". Thus weaponized, law itself hammers humanity into necessity, and human shields into human crosshairs. 